\title{
Ethnobotanical use of Morinda citrifolia: a literature review
}

\author{
Uso etnobotânico da Morinda citrifolia: uma revisão de literatura \\ Uso etnobotánico de Morinda citrifolia: revisión de la literatura
}

Received: 11/13/2021 | Reviewed: 11/18/2021 | Accept: 11/19/2021| Published: 11/20/2021

\author{
Sherlley Karoline de Araújo Souza \\ ORCID: https://orcid.org/0000-0003-4851-6623 \\ Universidade Salvador, Brazil \\ E-mail: sherlleysouza2016@gmail.com \\ Marcos Paulo Santos Passos \\ ORCID: https://orcid.org/0000-0001-9076-4650 \\ Universidade Salvador, Brazil \\ E-mail: marcos.passos@unifacs.br
}

\begin{abstract}
Plant biodiversity has long been used by people for different purposes. In this sense, ethnobotany studies the practices related to plants carried out by different social groups, analyzing people-plant interactions. Among this biodiversity, Morinda citrifolia $L$. stands out, generally native to the tropical region, and popularly known as noni. This fruit has broad medicinal potential due to its antioxidant, dyslipidemic, hypotensive, healing, and antimicrobial properties, among others. Therefore, the objective of this research was to identify the prevalence of the use of Morinda citrifolia, in addition to demonstrating works with plant-related intoxications. Therefore, a systematic literature review was performed based on a search in the Scielo database, using the descriptor "Morinda citrifolia", finding a total of 17 studies published from 2016 to 2021. After reading the title and abstract, 12 articles were selected for having greater relevance and affinity with the topic under study. The inclusion criteria used were productions in the public domain that dealt with the proposed theme, works written in several languages, and productions available in full, thus excluding documents that did not meet the aforementioned criteria. Literature analysis allowed us to identify the main uses of noni in the ethnobotanical aspect and its properties.
\end{abstract}

Keywords: Noni; Rubiaceae; Medicinal; Bioactive.

\section{Resumo}

A biodiversidade vegetal tem sido há muito tempo usada pelos povos para diversas finalidades. Nesse sentido, a etnobotânica estuda as práticas relacionadas a plantas realizadas por diversos grupos sociais, analisando assim as interações pessoas-plantas. Dentre essa biodiversidade, destaca-se a Morinda citrifolia L., geralmente nativa de região tropical, e popularmente conhecida como noni. Essa fruta possui amplo potencial medicinal devido suas propriedades antioxidante, dislipidêmico, hipotensor, cicatrizante, antimicrobiano, dentre outros. Diante disso, o objetivo dessa pesquisa foi identificar a prevalência do uso Morinda citrifolia além de demonstrar trabalhos com intoxicações relacionados a planta. Para tanto, foi realizada uma revisão sistemática da literatura a partir de uma busca na base de dados Scielo, utilizando o descritor "Morinda citrifolia", foi encontrando um total de 17 estudos publicados no período de 2016 a 2021 e após a leitura do título e resumo foram selecionados 12 artigos por apresentarem maior relevância e afinidade com o tema em estudo. Os critérios de inclusão utilizados foram produções de domínio público que tratassem do tema proposto, trabalhos escritos em diversas línguas e produções disponíveis na íntegra, excluindose assim os documentos que não atendiam os critérios supracitados. A análise da literatura permitiu identificar os principais usos do noni no aspecto etnobotânico e suas propriedades.

Palavras-chave: Noni; Rubiaceae; Medicinal; Bioativo.

\section{Resumen}

La biodiversidade vegetal ha sido utilizada durante mucho tempo por los pueblos para diferentes propósitos. En este sentido, la etnobotánica estudia las práticasrelacionadas con las plantas que llevan a cabo los diferentes grupos sociales, analizando asi las internacciones planta-persona. Entre esta biodiversidade se destaca Morinda citrifolia L. , generalmente originaria de la región tropical, y popularmente conocida como noni. Esta fruta tiene um amplio potencial medicinal debido a sus propiedades antioxidantes, dislipidêmicas, hipotensivas, cicatrizantes y antimicrobianas, entre otras. Por tanto, el objetivo de esta investigación fue identificar la prevalência del uso de Morinda citrifolia, además de demostrar trabajos com intoxicaciones relacionadas com plantas. Por ello, se realizó uma revisión bibliográfica sistemática a partir de uma búsqueda em la base de dados Scielo, utilizando el descriptor "Morinda citrifolia", encontrándose un total de 17 estudios publicados entre 2016 y 2021 y tras la lectura del título y resumen se seleccionaron 12 artículos por tener mayor relevancia y afinidad com el tema em estúdio. Los critérios de inclusión utilizados fueron producciones de dominio público que abordaran la temática propuesta, obras escritas em 
varios idiomas y producciones disponibles em su totalidade, excluyendo asi los documentos que no cumplieran com los criterios antes mencionados. El análisis de la literatura permitió identificar los principales usos del noni en el aspecto etnobotánico y sus propriedades.

Palabras clave: Noni; Rubiáceas; Medicinales; Bioactivas.

\section{Introduction}

Ethnobotany is the use of medicinal plants based on popular knowledge and is commonly spread among a community and scientific knowledge (Almeida et al, 2020). This use of medicinal plants by people is the oldest medication known in history and is passed on from generation to generation. These plants can be administered in the form of powder, tea, bath, and others, as long as the focus is on the use of complementary and alternative medicines, in medical care, and the promotion of their safe and effective use (Huilca \& Calahorrano, 2020).

Despite having this people-plant interaction for both subsistence and income generation, it is not always a sustainable relationship, so it is extremely important to study local traditional popular knowledge with natural resources and the availability of these resources (Gomes, 2019).

According to Valeriano et al (2019), the use of medicinal plants is an ancient practice, mainly of traditional populations, such as Indians and caiçaras among others, which has been transferred between generations over time and is added to a historical, socioeconomic and cultural.

Brazil has a plant genetic mega biodiversity that can be observed by a variety of biomes, with emphasis on great medicinal potential (Lisboa et al., 2021), according to Pacheco and Almeida (2022). This plant diversity encourages and favors the discovery of new bioactive compounds, mainly from medicinal plants that can be a food source, in addition to being used in ornamentation and as herbal medicines, as they have bioactive principles (Omar et al., 2020).

Among this biodiversity, Morinda citrifolia $L$. stands out, generally native to the tropical region, and popularly known as noni, belonging to the Rubiaceae family. The chemical makeup of the family is broad and has approximately 200 phytochemicals isolated and identified from various parts of the plant as roots, leaves, bark, and fruit (Palioto et al, 2015), with broad medicinal potential due to its antioxidant, dyslipidemic, hypotensive, healing, antimicrobial, analgesic properties (Souza et al, 2019; Vasconcelos et al, 2021), anticancer, anti-inflammatory, antidiabetic, antituberculosis, anxiolytic, antipsoriasis (Abou Assi et al, 2017), micronutrients such as phenolic compounds, organic acids and alkaloids (Franchi ET AL 2013), in addition to having a high toxic potential of some plants in this family. Used for years in the use of fruit juice for various purposes, noni has activities: antibacterial, antiviral, antifungal, antitumor, anthelmintic, analgesic, hypotensive, and antiinflammatory (Barbosa, et al, 2017). It is also used in traditional medicine, followed by the fruits, there are roots, and leaves.

Furthermore, regarding chemical aspects, the main classes of compounds isolated from M. citrifolia belong to flavonoids (Long et al., 2009), lignans, triterpenoids (Lishuang et al., 2011), iridoids (Kamiya et al., 2008), and anthraquinones, as well as compounds derived from benzophenone, called morithrinfolines (Deng et al., 2011).

In this context, the objective of this study is to identify the prevalence of Morinda citrifolia use in popular use, in addition to demonstrating works related to the plant that there were intoxications.

\section{Methodology}

This work is a systematic literature review of a descriptive nature, with a qualitative approach, which focuses on the knowledge produced and published in books, journals, and articles on the use of M. citrifolia. According to Tonetto (2014), the descriptive type of research is usually used when one wants to map reality, using data collected through the internet and computerized methods to carry out analyses. Also, in a descriptive character, according to Triviños (2008), the facts are carefully described with the reality of the information that has already been defined as a problem to be investigated. 
Thus, a bibliographic survey was carried out in Scielo databases, using the following descriptor: Morinda citrifolia. In the search, 17 studies were found, published in the period from 2006 to 2021, and after reading the title and abstract, 12 articles were selected for showing greater relevance and affinity with the topic under study. The inclusion criteria used were productions in the public domain that deal with the proposed theme, works written in several languages, and productions available in full, thus excluding documents that did not meet the aforementioned criteria.

\section{Results and Discussion}

Plant biodiversity has long been used by people for various purposes such as food, medicine, ornamentation, among others, mainly because of the essential elements that are provided for the maintenance of human life. In this context, ethnobotany emerges, which is a science/field that studies the practices related to plants carried out by different social groups, thus analyzing people-plant interactions (Ferreira et al, 2020). However, some medicinal and ornamental plants can also be toxic. According to Pohl and Driemeier (2021), some plants can even cause acute hepatotoxicity, causing economic losses. According to Pessoa et al (2019), in Brazil, there are about 131 species of toxic plants, divided into 79 genera. Some plants are so toxic that they can even cause sudden death due to the monofluoroacetate compound (MFA), among these plants the family stands out: Rubiaceae, Malpighiaceae, and Bignoniaceae (Arruda et al, 2017). Thus, it is important to identify the prevalence of popular use of $M$. citrifolia and demonstrate whether there was already intoxication with the use of the plant. Therefore, Table 1 shows the summary of selected articles with their authors, published journal, and year of publication (Table 1). 
Table 1 - Studies addressing summary of selected articles with their authors, published journal, and year of publication.

\begin{tabular}{|c|c|c|}
\hline Title & Authors & Journal/Year \\
\hline $\begin{array}{l}\text { Primeiro registro de Atta sexdens rubropilosa Forel, } \\
1908 \text { (Hymenoptera: Formicidae) atacando noni (Morinda } \\
\text { Citrifolia L.) em Colorado do Oeste (RO), Brasil }\end{array}$ & Matte et al. & $\begin{array}{l}\text { Scientific } \\
\text { communication } \bullet \text { arq. } \\
\text { Biol./2016 }\end{array}$ \\
\hline $\begin{array}{l}\text { The morphological characterization of the dry seeds } \\
\text { and reserve mobilization during germination in Morinda } \\
\text { citrifolia } 1 .\end{array}$ & Paula et al. & Ciênc. Agron $/ 2016$ Science $\bullet$ Rev. \\
\hline $\begin{array}{l}\text { Eficacia in vitro de Morinda citrifolia L para } \\
\text { elcontrolde Rhipicephalus (Boophilus) microplus } \\
\text { Ixodidae) }\end{array}$ & Napoles et al. & $\begin{array}{ll}\text { Revista } & \text { Investigação } \\
\text { vet. Perú. /2016. }\end{array}$ \\
\hline $\begin{array}{l}\text { Mortalidade de larvas de spodoptera frugiperda por } \\
\text { efeito de extratos de frutos de morinda citrifolia l. (noni) }\end{array}$ & Varela \& Luna & $\begin{array}{l}\text { Revista } \\
\text { Quim/2017. }\end{array}$ \\
\hline $\begin{array}{l}\text { Comportamento reológico das polpas de noni integral e } \\
\text { concentradas }\end{array}$ & Sousa et al. & $\begin{array}{c}\text { Revista } \\
\text { journal of food Technol/2017. }\end{array}$ \\
\hline $\begin{array}{l}\text { Ultrasonic extracts of Morinda citrifolia } 1 .: \\
\text { characterization of volatile compounds by gas chromatography- } \\
\text { mass spectrometry }\end{array}$ & Lima et al. & $\begin{array}{l}\text { Revista } \\
\text { journal of food Technol/2019. }\end{array}$ \\
\hline $\begin{array}{l}\text { A influência da pasteurização e da cultura starter no } \\
\text { teor de metanol e no bio-perfil do fermentado Morinda } \\
\text { citrifolia linn. (noni) suco de fruta }\end{array}$ & Saelle et al. & $\begin{array}{l}\text { Food Science and } \\
\text { Technology/2020. }\end{array}$ \\
\hline $\begin{array}{l}\text { Potencial nutricional e bioativo do noni cultivado no } \\
\text { estado de mato grosso }\end{array}$ & Vasconcelos & Rev Ciência Rural/ \\
\hline $\begin{array}{l}\text { Morinda citrifolia: fatos e riscos sobre o uso do } \\
\text { noni }\end{array}$ & Barbosa et al. & Revista Fitos/2017. \\
\hline $\begin{array}{l}\text { Morinda citrifolia (noni): uma revisão dos seus } \\
\text { efeitos biológicos }\end{array}$ & Mororó et al. & Revista vinter/2017. \\
\hline $\begin{array}{l}\text { Hepatotoxicidad grave asociada al consumo de } \\
\text { Noni (Morinda citrifolia). }\end{array}$ & Andrada et al. & Revista Fitos/ 2007 \\
\hline $\begin{array}{l}\text { Mineral variability among } 177 \text { commercial noni } \\
\text { juices. }\end{array}$ & West & $\begin{array}{l}\text { International Journal of } \\
\text { Food Sciences and Nutrition. } \\
2006 \text {. }\end{array}$ \\
\hline
\end{tabular}

Source: Authors.

In Brazil, the culture of noni is recent. In the last decade, its commercial cultivation and consumption have increased due to its medicinal properties. The fruit peel is used to treat malaria, the leaves to treat inflammation and as an analgesic, the flowers in eye inflammations and seeds are used as a laxative (Matte et al, 2016). In the same year, Paula et al spoke about the therapeutic potential of noni, highlighting the use of noni juice against diseases such as diabetes, muscle pain, heart disease, and for having a preventive effect against cancer. According to Napoles et al (2016), M. Citrifolia has medicinal properties in the fruits, roots, bark, seeds, and in particular, the leaves, which have distinct activities such as anti-inflammatory, astringent, analgesic, antiseptic and anthelmintic.

Also, Varela et al (2017) still highlight the insecticidal property in which, with their use of noni extract, due to some secondary metabolites, they act as a defense against infections and attacks, including insects, thus having no environmental impact. The authors also emphasize the high productivity at very low cost and low toxicity for vertebrates. Sousa et al (2017) show that noni has expanded in regions of Brazil not only because it has a rich source of nutrients, but mainly because of its herbal properties.

According to Barbosa et al (2017), in addition to the plant being used to treat cancer and diabetes, it is also used for menstrual disorders, hypertension, and arthritis, highlighting the most used parts of the fruits, followed by the roots and leaves being assigned to each part of the plant a different medicinal property. According to Barbosa et al (2017), studies were carried out showing reports of hepatotoxicity with the consumption of noni (Stadbauer et al, 2005). Also, poisoning was reported with the ingestion of juice in a patient (West, 2006) among others, causing hepatitis, and interfering with liver enzymes (Mororó et 
al, 2017). Andrada et al (2007) found abdominal pain, vomiting, and nausea in a patient who had ingested noni, requiring further clinical studies.

Lima et al (2019), cited the herbal effects of noni, showing anti-inflammatory, analgesic, and diuretic activities, in addition to vitamin $\mathrm{C}$ and $\mathrm{E}$ in large amounts that are similar to those of acerola and papaya. Also, they mentioned some acids such as octanoic, decanoic, ursolic, linoleic.

According to Saelle et al (2020), noni fruit juices have sources of functional components such as prebiotics that house and support the survival of probiotic strains, such as Lactobacillus spp. and Bifidobacterium spp. The use of noni in the commercial and pharmacological area (juices, insecticides, and pharmacological potentials) is also highlighted. Finally, Vasconcelos et al (2021), in addition to highlighting the popular use of the fruit against several diseases mentioned above, considered the noni pulp as a potential antioxidant reducing the concentration of free radicals.

\section{Conclusion}

Through this work, we observed that $M$. citrifolia (noni) is popularly used in traditional medicine mainly because of the different bioactive principles and pharmacological properties, promoting the use of different parts of the plant, whether leaf, root or any other another. However, due to the ingestion of excessive amounts or inadequate preparation, poisoning can occur, causing hepatotoxicity.

\section{References}

Abou, A. R., Darwis, Y., Abdulbaqi, I. M, Khan, A. A, Vuanghao, L., \& Laghari, M. H (2017). Morinda citrifolia (Noni): Uma revisão abrangente sobre seus usos industriais, atividades farmacológicas e ensaios clínicos. Arabian Journal of Chemistry, 10 (5), 691-707.

Arruda, F. P., Caldeira, F. H. B., Ducatti, K. R. (2017). Experimental poisoning by Niedenzuella stannea in cattle and corresponding detection of monofluoroacetate. Ciência Rural, 47(3).

Almeida, C., Vaz Ribeiro, M., Kaster, P. M. (2020). Inter-relações no cuidado com as plantas medicinais - “vem de berço.” Enfermería: Cuidados Humanizados, 9(2), 229-242,

Andrada, J. M. L. P., Castilha, S. L., Olvera, M. D. F., Vidal A. A. (2007), Hepatotoxicidad grave asociada al consumo de Noni (Morinda citrifolia). Revista Espanhola de Enfermidades Digestivas. 99(3): 173-181.

Barbosa, A., Costa, I., Zucolotto, S. (2017). Morinda citrifolia: fatos e riscos sobre o uso do noni. Revista Fitos, 11(2).

Deng, S., West, B. J. Antidepressant effects of noni fruit and its active principals. Asian Journal Of Medical Sciences. (2011), 3(2): 79-83.

Franchi, L. P., Guimaraes, N. N., Andrade, L. R. (2013). Antimutagenic and antirecombinagenic activities of noni fruit juice in somatic cells of Drosophila melanogaster. Anais da Academia Brasileira de Ciências, 85(2), 585-594,

Ferreira, A. L. S., Pasa, M. C., Nunez, C. V. (2020). A etnobotânica e o uso de plantas medicinais na Comunidade Barreirinho, Santo Antônio de Leverger, Mato Grosso, Brasil. Interações (Campo Grande), 817-830.

Gomes, C. C. (2019). Potencial utilitário da vegetação lenhosa em área de Caatinga no estado de Pernambuco, nordeste do Brasil. Ciência Florestal, 29(1), 307 ,

Huilca, I., Zavala, C. A. (2020). Uso de plantas medicinales en las mujeres de la Sierra Centro, Ecuador durante el postparto. Vive Revista de Salud, 3(9), 198212 ,

Kamiya, K., Hamabe, W., Harada, S., Murakami, R., Tokuyama, S., Satake, T. (2008) Chemical constituents of Morinda citrifolia roots exhibit hypoglycemic effects in streptozotocin-induced diabetic mice. Biologycal and Pharmaceutical Bulletin. 31(5):935-38.

Lima, D., Dos Santos, A., Celestino, A. Ultrasonic Extracts of Morinda citrifolia L.: Characterization of Volatile Compounds by Gas Chromatography-Mass Spectrometry. Journal of the Brazilian Chemical Society, (2019).

Lishuang, L. V. (2011). Chemical components of the roots of Noni (Morinda citrifolia) and their cytotoxic effects. Fitoterapia. 82(4): 704-708.

Lisboa, T., Cielo-Filho, R., \& Câmara, C. (2021). Florística e fitossociologia do componente arbóreo-arbustivo de mata ciliar em estágio inicial de sucessão na microbacia do rio Xaxim (Oeste do Paraná, Brasil): subsídios para a restauração ecológica. Lilloa, 58(1), 15-34

Long, X. Y., Jiang, M. H. K., \& Liu, J. (2009), Chemical Constituents from the Seeds of Morinda citrifolia. Chinese Journal of Natural Medicines. 7(2): $119-22$ 
Matte, W. D., Queiroz, L. Fde., Corassa, J. N. (2016). Primeiro registro de Atta sexdens rubropilosa Forel, 1908 (Hymenoptera: Formicidae) atacando noni ( Morinda Citrifolia L.) em Colorado do Oeste (RO), Brasil. Arquivos do Instituto Biológico, 83

Mororó, A. V. T. P., Carvalho, M. J. M., de, Araújo, N. T. P., Cavalcante, A. L. C., Catunda Júnior, F. E. A., Bezerra, S. B., Cerqueira, G. S., \& Siqueira, R. M. P. (2017). Morinda citrifolia (noni): uma revisão dos seus efeitos biológicos, 10(2).

Nápoles, V., Darién, S. R., Kenia, M., Colas, C. M. (2017). Eficacia in vitro de Morinda citrifolia L para el Control de Rhipicephalus (Boophilus) microplus (Acari: Ixodidae). Revista de Investigaciones Veterinarias del Perú, 27(4), 833

Omar, G., Abdallah, L., Barakat, A. (2020). In vitro haemostatic efficacy of aqueous, methanol and ethanol plant extracts of three medicinal plant species in Palestine. Brazilian Journal of Biology, 80(4), 763-768,

Pacheco, A. G. M., \& Almeida. (2022) Atividades antinociceptiva e antiinflamatória de Hymenaea martiana Hayne (Fabaceae) em camundongos. Revista Brasileira de Biologia. 82.

Palioto, G. F., Silva, C. F. G., Mendes, M. P. (2015). Composição centesimal, compostos bioativos e atividade antioxidante de frutos de Morinda citrifolia Linn (noni) cultivados no Paraná. Revista Brasileira de Plantas Medicinais, 17(1), 59-66.

Paula, S. O., Sousa, J. Á., Brito, E. S. (2016). The morphological characterization of the dry seeds and reserve mobilization during germination inMorinda citrifoliaL. Revista Ciência Agronômica, 47(3), 556-563

Pessoa, D. A. N., Medeiros, R. M. T., Riet, C. F. (2019). Techniques for prevention and control of poisoning by sodium monofluoroacetate (MFA)-containing plants in ruminants. Pesquisa Veterinária Brasileira, 39(10), 771-779.

Pohl, C. B., Hammerschmitt, M. E., Molossi, F. A. (2021). Spontaneous poisoning by Cestrum intermedium in dairy cattle. Pesquisa Veterinária Brasileira, 41.

Saelee, M., Sivamaruthi, B. S., \& Sirilun, S. (2020). The influence of pasteurization and starter culture on methanol content and bio-profile of fermented Morinda citrifolia Linn. (Noni) fruit juice. Food Science and Technology, 40(3), 621-628.

Sánchez, V. A., \& Isabel, L. (2017). Mortalidad de larvas de spodoptera frugiperda por efecto de extractos de fruto de morinda citrifolia 1. (noni). Revista Boliviana de Química, 34(5), 138-141.

Sousa, S. F., Queiroz, A. J. M, \& Figueirêdo, R. M. F. (2017). Comportamento reológico das polpas de noni integral e concentradas. Brazilian Journal of Food Technology, 20.

Souza, M. C. M. R., Menezes, A. S., \& Costa, R. S. (2019). Saline water on the leaf mineral composition of noni under organic fertilization. Revista Brasileira de Engenharia Agrícola e Ambiental, 23(9), 687-693,

Tonetto, L. M., Brust, R. P. G., \& Stein, L. M. (2014). Perspectivas metodológicas na pesquisa sobre o comportamento do consumido. Psicologia: Ciência e Profissão, 34(1), 180-195,

Triviños, A. N. da S. Introdução à pesquisa em ciências sociais: a pesquisa qualitativa em educação. Revista Atlas, (2008).

Vasconcelos, I. P de., Silva, V. E. R., \& Costa, P. M. C. (2021). Nutrition and bioactive potential of the noni fruit cultivated from the Mato Grosso State. Ciência Rural, 51(2)

Valeriano, F. R., Savani, F. R., \& Silva, M. R. V. D. A. O uso de plantas medicinais e o interesse pelo cultivo comunitário por moradores do bairro São Francisco, município de Pitangui, MG. Interações (Campo Grande), 891-905, (2019).

West, B. J. Mineral variability among 177 commercial noni juices. International Journal of Food Sciences and Nutrition. (2006), 57(7-8): 556-558. 